\title{
Study of Green Behavior with a Focus on Mexican Individuals
}

\author{
Eva CONRAUD-KOELLNER ${ }^{1}$, Luis Arturo RIVAS-TOVAR ${ }^{2}$ \\ ${ }^{1}$ Universidad de Guanajuato, Guanajuato, Mexico; ${ }^{2}$ Instituto Politecnico Nacional, Mexico City, Mexico. \\ Email: evac@quijote.ugto.mx, larivas33@hotmail.com
}

Received September 20, 2009; revised October 28, 2009; accepted November 27, 2009

\begin{abstract}
Studies of green behavior have awakened a growing interest, since the accelerated environmental degradation is partly attributed to a lack of such behavior. However it is not an easy task to modify consumer habits and influence the behavior of individuals. This paper summarizes variables extracted from four models of green behavior in five core groups: orientation man-nature, perceived control, ecological knowledge, personal consequences and environmental consequences, with a special focus on the Mexican individuals as an example of application of environmental marketing strategies. Analysis shows that in spite of efforts done in environmental management in Mexico, one of the 12 environmentally megadiverse country of the world, there is a big gap between official programs to protect environment and social participation. In the particular case of Mexico, it is recommended to relate environmental issues to survival process, in order to apply efficient environmental marketing strategies.
\end{abstract}

Keywords: Green Behavior, Mexican Individuals, Environmental Marketing Strategies

\section{Introduction}

Studies of green behavior have awakened a growing interest, since the accelerated environmental degradation is partly attributed to a lack of such behavior. However it is not an easy task to modify consumer habits and influence the behavior of individuals. The review of literature regarding green behavior reveals preference for variables related to values or attitudes (or changes in attitudes) or external variables of the individuals, mainly the situational, that occupy a prominent position in these studies [1-8]. Studies focus especially on social standards and the physical environment where specific behaviors occur, observing how these are fomented or obstructed by the conditions of the environment $[9,10]$. This paper summarizes variables extracted from four models of green behavior in five core groups: orientation man-nature, perceived control, ecological knowledge, personal consequences and environmental consequences, which are described below, with a special focus on the Mexican individuals as an example of application of environmental marketing strategies.

\section{Models of Green Behavior}

The four models found in recent specialized literature are briefly described here below:

The conceptual model of the behavior of ecological purchase, developed in 2004 by Chan and Lau [1] suggests that the values that traditionally govern the relation of the individuals with nature (orientation man-nature) influence directly the amount of knowledge that a person has about environmental topics (ecological knowledge), and the level of emotional attachment and commitment that an individual shows towards the environment (ecological feeling). And they conclude that purchase behavior depends on the individual's purchase intention of green products. This model can be described in the following Figure 1.

The model of the environmentally responsible purchase developed by Follows and Jobber [2], predicts the purchase of a specific type of environmentally responsible product based on three variables: self importance (or pro-social) values, conservation values, and individualistic values. These refer to the factors that motivate people to put their own interests over any other thing. Follows and Jobber propose that the goals of an individual person's self-indulgence and self reward are consistent with the interest in the individual consequences, and act in a negative way on the environment. The model is presented in the following Figure 2.

The model of the Theory of Behavior developed by Ajzen adapted to the study of the consumer purchase 


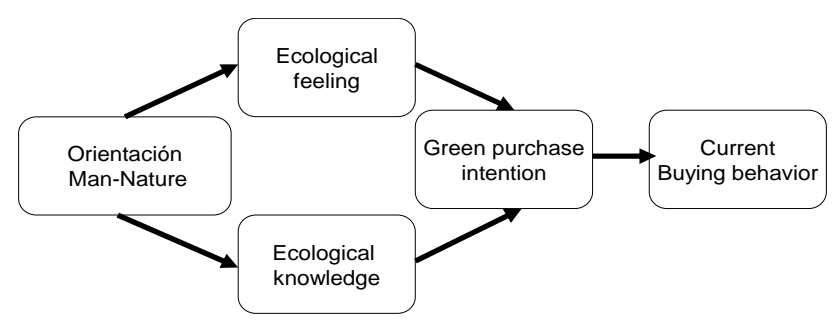

Figure 1. Conceptual model of the behavior of ecological purchase

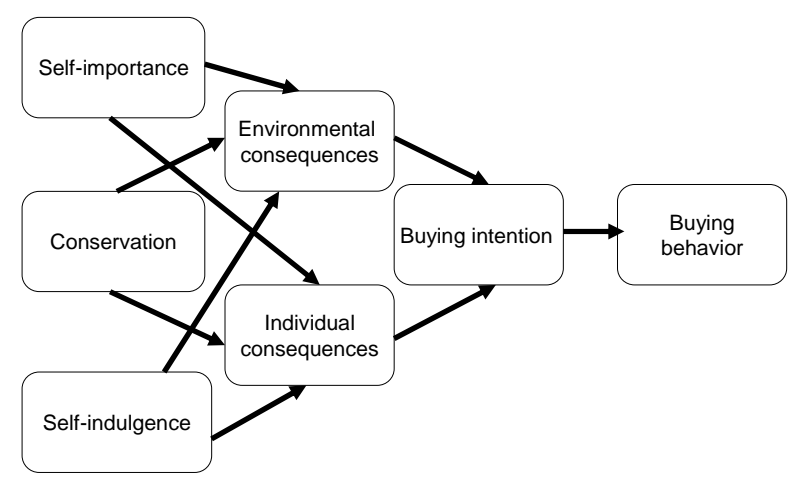

Figure 2. Model of the environmentally responsible purchase

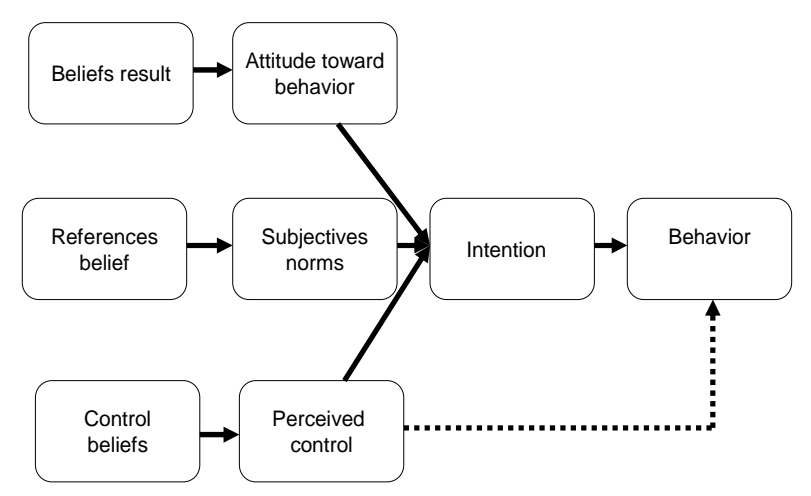

Figure 3. Model of the theory of behavior

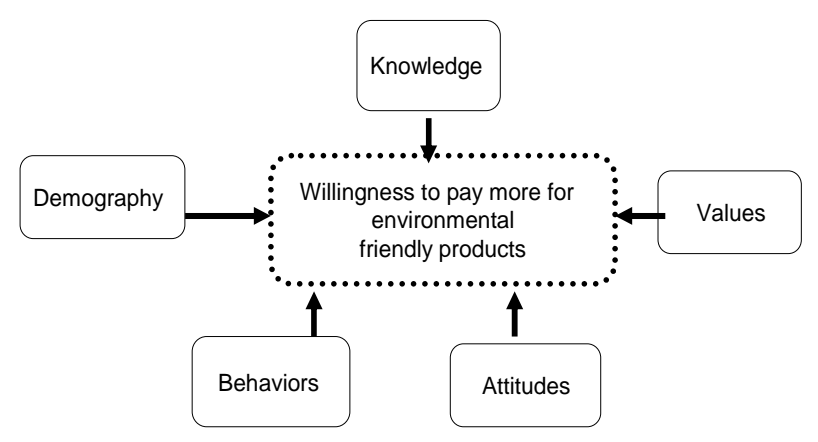

Figure 4. Model of the ecological behavior of purchase and the willingness to pay a higher price

behavior in green markets in 1999 by Stavros P. Kala- fatis [3] and their team of collaborators. The variables that this model proposes are: the beliefs, the result and the attitude towards the behavior, the reference beliefs and subjective norms; and these last ones are the guidelines that individuals are taking in consideration when they decide what they must or must not do, as presented in Figure 3.

The model of the ecological behavior of purchase and the willingness pays a higher price developed by Laroche, Bergeron and Barbaro-Forleo [4]. It focuses on the study of the factors that determine the willingness of individuals to pay a higher price for environment friendly products. These factors can be grouped in three categories: demographic characteristics, level of knowledge, and values and attitudes that consumers have (or adopt) towards environmental topics. The model is presented in Figure 4.

Table 1 shows five main common variables extracted from these models to provide further insights about green behavior: orientation man-nature, perceived control, ecological knowledge, personal consequences, and environmental consequences; with the purpose of eventually applying them in environmental marketing strategies.

For this specific study these five variables are being related to some interesting results found in surveys applied to Mexican individuals regarding their green behavior, in order to suggest some recommendations on how to launch an efficient environmental marketing campaign in Mexico.

\section{Orientation Man-Nature}

This variable represents the values that govern the relationship between men and nature. The degree of awareness towards environmental problems is revealed as one of the key factors of green behavior. It is therefore important for an organization to determine the level of awareness in its potential market, especially regarding environmental issues directly related to its activity or product. This level of awareness is driven by ecological consciousness, which is present in most of the models of green behavior [11,12]. Barreiro et al. [13] divide consciousness in cognitive and emotional aspects; that is, those related to the ecological knowledge of individuals and to their environmental awareness, focused on general ecological attitudes. Green consciousness is understood as a feeling, a representation, an image, a purpose, an attitude, a course of action, and a trend of behavior whose main value is to protect the environment and improve quality of life [14]. As mentioned before, this green consciousness is the starting point for the generation of green consumer behavior. Ecological behavior is defined as "the action that one person does, either individually or collectively, in favor of the conservation of natural resources and aimed to obtain a better quality of 
Table 1. Variables of this study

\begin{tabular}{|c|c|c|c|c|c|}
\hline \multicolumn{2}{|c|}{ Models } & $\begin{array}{c}\text { Theory of the behav- } \\
\text { ior of the ecological } \\
\text { purchase } \\
\text { Kalafatis S.P. et. Al } \\
\text { (1999) }\end{array}$ & $\begin{array}{l}\text { Model of the envi- } \\
\text { ronmentally responsi- } \\
\text { ble purchase } \\
\text { Follows-Jobber } \\
\text { (2000) }\end{array}$ & $\begin{array}{c}\text { Conceptual model of } \\
\text { the behavior of eco- } \\
\text { logical purchase } \\
\text { Chan-Lau } \\
(2000)\end{array}$ & $\begin{array}{l}\text { Model of the behavior } \\
\text { of ecological purchase } \\
\text { and willingness to pay } \\
\text { a higher price } \\
\text { Laroche et. Al(2001) }\end{array}$ \\
\hline \multirow{6}{*}{$\begin{array}{l}\text { Independent } \\
\text { ables }\end{array}$} & \multirow{6}{*}{ vari- } & Beliefs result & Self-importance & $\begin{array}{l}\text { Orientation } \\
\text { man-nature }\end{array}$ & Demography \\
\hline & & References beliefs & Conservation & Ecological feeling & Knowledge \\
\hline & & Control beliefs & Self-indulgence & Ecological knowledge & Values \\
\hline & & Behavior & $\begin{array}{l}\text { Environmental conse- } \\
\text { quences }\end{array}$ & & Behaviors \\
\hline & & Subjective norms & $\begin{array}{l}\text { Individual conse- } \\
\text { quences }\end{array}$ & & Attitudes \\
\hline & & Perceived control & & & \\
\hline \multirow{2}{*}{$\begin{array}{l}\text { Dependant } \\
\text { ables }\end{array}$} & \multirow[t]{2}{*}{ vari- } & Intention & Buying intention & Green buying intention & $\begin{array}{l}\text { Willingness to pay a } \\
\text { higher price }\end{array}$ \\
\hline & & Behavior & Purchase behavior & $\begin{array}{c}\text { Current purchase be- } \\
\text { havior }\end{array}$ & \\
\hline
\end{tabular}

the environment"[15]. Barreiro et al. [13] emphasize that the environmental consciousness of individuals is divided into two main attitudes: a first related to the concern that suggests the protection of the environment, with special references to issues regarding the pollution of that environment; and a second one related to the impression that individuals have of who is truly responsible for protecting that environment and should, by their actions, be concerned about making decisions that will help to solve these problems; in this case, they detected that individuals believe those who should indeed be responsible are countries, governments and, the society in general, assuming that they could not themselves do anything to protect the environment [16].

On the contrary, values can significantly reduce green behavior, although they would hardly eliminate it entirely. Stern, Dietz and Kalof [17] classify the values in three groups: values of selfish orientation, that represent the concern for oneself; values of biosphere orientation, that represent the concern for non-human species and the biosphere as a whole; and values of social or altruistic orientation, that show concern for others. Under this scheme, if people are more oriented towards biosphere values, one could expect that their beliefs about ecological behavior would consider the consequences of some behavior on the environment, whereas if people privilege selfish values, their beliefs would be based on the evaluation of the possible consequences for themselves. In contrast, if people are concerned about others, their beliefs should also be oriented towards the consequences of their behavior on others.

Some studies point to women as more concerned about environmental issues and ecological behaviors [17-19]. However, Zelezni, Chua and Aldrich [20] indicate that environmentalism does not start in adulthood, and refute the argument that women are more concerned with environmental issues because of their maternity and their interest in protecting their family from environmental threats. A revision of the literature [21-24] also highlights evidence of green conscience in western countries, reflected in the consumer's decisions to buy environmental friendly products and actions taken by companies and governments to sustain this interest and sensibility with the generation of green products on one hand, and the adoption of laws to protect the environment on the other hand.. However, Elliott [25] emphasizes the difficulty companies can have in implementing green measures and even some resistance by consumers to accepting these green technologies, and suggests that these be accompanied with social, economics and political strategies. Rivera-Camino [26], Straughan R. D and Roberts J. A., [27], and Tadajewski y Wagner-Tsukamoto [28] agree to the above, showing in addition the importance of considering demographic, anthropological and psychological aspects to more effectively identify the profile of the targeted market segment in order to apply efficient environmental marketing strategies.

\section{Perceived Control}

This variable determines the degree of responsibility individual feel towards their possibilities to reduce pollution problems. Attitudes and general environmental concerns are not necessarily predictors of attitudes and behavior regarding specific or isolated acts. In fact, a person may show a favorable attitude towards the environment in general and a negative attitude towards recycling, e.g. by considering this process uncomfortable. It is also quite possible that each concrete ecological behavior 
(purchase, recycling, etc) could involve specific variables and influence in different directions and means. In her study of values and attitudes on environmental pollution in Mexico, Durand [16] reveals that in the specific case of Mexicans, fewer are willing to make an effort to collaborate in the war against pollution than those who are not. On the other hand, when they believe that pollution is not a serious issue, the number of Mexicans who are willing to collaborate will increase. In other words, the willingness of Mexicans to act apparently occurs in inverse proportion to the perceived gravity of the problem, which probably means that under very negative environmental circumstances the effort of collaboration by individuals loses its meaning or is considered worthless with regard to the size of the challenges. This is an important result as to the way the environmental problem is being publicized, since presenting problems such as pollution or deforestation to the people in an alarming way without relating them to potential solutions at their reach may paralyze or decrease their capacity to act. Truly, the concerns of people and their interests are associated with their daily lives and their particular world. According to Hernandez et al. [29] the perception of ecological crime is very different, whether the non-environmental behavior is affecting one's own convenience and/or banking accounts. As to the willingness to recycle, Diaz and Palacio [30] show that the recycling behavior of consumers can not only be better represented through a model of habit or low-involvement routine "know-dofeel" than through the classical hierarchy "know-feel-do", but it can also be represented through other models such as the hedonic "feel-do-know" and the reverse learning "do-feel-know". In addition, the age and zone of residence and to a lesser extent gender, level of studies, and income affect the way in which the consumers recycle. Also domestic conditions and the existence of legal and economic incentives foment a slightly different recycling response. Pato [31] describes the possibility of multiples causes that influence a proactive ecological behavior, characterized by actions related with the preservation and conservation of the environment, and with buying decisions and use of products considered environmental friendly, or a decision to reject products perceived as harmful to the environment. Thereon Pato y Tamayo [32] indicate that the proactive behavior suggests that individual and collective actions benefit the collective indistinctly, and would imply equality of recognition of the persons subject to these actions. Similarly these actions generally seek to improve conditions and quality of life, and suggest respect of other people, and even other forms of life. They add that it is different to claim that a specific value does not produce any effect on an ecological behavior more than saying that such value influences the

\footnotetext{
${ }^{1}$ Www.environmentalleader.com.

${ }^{2}$ www.mangosprouts.com
}

beliefs people have on the environment, making them receptive to act in a pro or anti ecological manner. D’Souza and Taghian [33] reiterate this assertion, by proving the relationship between consumers's appreciative of and reactions to green advertisement, and their low or high feeling of commitment to the environment. Regarding the later it is interesting to mention the conclusion of a survey applied in Europe by Munuera at al. [34], who emphasize the importance of cultural background in the decision to purchase green products.

As mentioned earlier, the decision to buy green products may be affected by the surroundings and socioeconomic circumstances. There are also some controversies in terms of the perception consumers have of green products. According to a survey launched at the beginning of 2008 by the marketing agency Ecoalign ${ }^{1}$, even though there is a great concern for the environment, consumers think that many forms of green technology (renewable and recycled material) are expensive, difficult to understand and take care of, and not very esthetically attractive. This is being confirmed by Elliott [25]. In contrast, according to the Mango Sprouts ${ }^{2}$ agency's survey, consumers are not only willing to pay up to $5 \%$ more for environmentally friendly products [35-38] , but are looking to support companies and distribution centers that have adopted green practices with their purchases.

\section{Ecological Knowledge}

This variable defines the sets of ecological knowledge that an individuals have of environmental topics. According to Barreiro et al. [13], the knowledge of environmental problems can be in a continuum ranging from mere knowledge of their existence to the detailed knowledge of their causes, effects, affected areas, actors responsible for the problem, solutions, and agents responsible for these latest. Such knowledge can derive mainly from three sources:

- Cultural tradition:

It is called the ecological ethnocentrism;

- Diffusion of scientific knowledge on these issues:

Increasingly, environmental issues are more present in the media, school curriculum and numerous recreational activities. This results in "socialization" with new and greater environmental content.

- Personal experience of problems, their risks and effects:

Personal experience only counts if the person has developed some sort of cognitive scheme based on their experience. This scheme must include some insight into its definition, its causes, effects and extent, and those responsible for provoking and resolving the problems.

The degree of information someone has on a given environmental problem will largely determine their opinion regarding this problem. What is true is that not all environmental problems require the same amount of previous 
information, since "familiarity" with some of them provides this knowledge through one's own experience. For that the scale of the problem, i.e. its proximity and/or reach, its intensity or frequency, and its compatibility with other problems and social needs are the main features that condition the knowledge and the appreciation of the problems-and eventually, the corresponding behavior. Ecological knowledge is also supported by past behavior and perceptions about recycling and second-hand products purchase. According to research from Aguilar et al. [39] past behavior directly influences the intention to recycle, as part of green behavior. He emphasizes the significant and independent contribution of past behavior to the variance of the intention, once variables such as attitudes, social norms or perception of behavioral control are taken into account. Gregson \& Crewe [40] also describe second-hand purchasing as an alternative form of green consumption, implying therefore a change in the perception of used goods, otherwise interpreted as waste.

\section{Individual Consequences}

This variable determines the degree of knowledge that a person has of the individual consequences of a pollution problem, or on the contrary, of a more friendly action on the environment. In relation to the individual consequences, Durand [16] contradicts previous positions expressed by Inglehart [41], suggesting that environmentalists' values emerge when caring for the environment is transformed into a new component of security or individual well-being, i.e. when it becomes part of a survival process. Thus, it does not only occur in wealthy sectors, but also in less favored ones. According to Inglehart [41], from the perspective of the theory of post-material value changes, materialistic values linked with economic security are substituted by postmaterial values or associated to emotional, esthetic or intellectual needs. Supported by the hypothesis of scarcity, the author explains that in those societies that have met their basic needs, individuals and social groups grant less importance to materialistic values (economical success, public and individual security) and come to worry about things that are now more complicated to get, usually related to the quality of life and social relationships affected by industrial development. It's only once men and women have satisfied those needs that they consider prioritary or live according to those values they consider primary, that they will eventually seek new goals, and new values will emerge to guide them towards these goals. In postmaterial societies the environmental problem is being reacted to by concern for global warming, pollution, and transgenesis. While in less prosperous societies, problems such as bad harvests, flood, and diseases are standing out. In this case, the concern for environmental issues may occur in nonindustrial countries as a component of personal security, that is, as a new material value. Durand [16] argues that it is likely that in non postindustrial societies, such as Mexico, environmental values emerge from the coexistence of interest and priorities that respond to the confluence of both industrializing and post industrial structures. From the survey the author did on environmental pollution in Mexico [16], interesting results emerged concerning individual consequences that the surveyed Mexicans perceived. Among other interesting findings was that the majority of the respondents questioned the existence of environmental problems, that is, they are not sure if those who talk about pollution are overreacting, or are fighting a real problem. They consider that some social purposes, such as the need to create jobs may justify the existence of environmental pollution. Another interesting point that Durand shows [16] is the correlation between level of education and income with the awareness of environmental problems. Indeed the results of the survey show that the environmentalism index only relates to those groups that have a better standard of living. The author also points out that having environmentals values does not depend on having either postmaterial values or a high standard of living. It surely increases with socioeconomical status, but analysis reveals that environmentalism in less advantaged sectors is accompanied with material values, i.e. tied to survival.

\section{Environmental Consequences}

This variable determines the degree of knowledge that individuals have of the environmental consequences of a lifestyle or a behavior. Barreiro et al. [13] manifest that the global dimension of the problem of environmental degradation has converted it into a "global" problem, clearly exposing the insufficient measures adopted individually by each nation. Conservation of the natural environment is a concern that transcends borders; therefore a planetwide joint action becomes necessary to achieve the combination of economic growth and the environment conservation once and for all. Since the end of the 20th century, the green house effect, air and see pollution, and the destruction of the ozone layer have been some of the problems perceived by a growing number of population sectors, who are making worthy efforts to produce, through economical, social and political strategies, radical changes in the production process of industrialized societies characterized by high consumption. Durand [16] indicates that the appreciation of environmental care can be manifested in actions or incorporated in lifestyles when factors that determine wellbeing, in the short or long term, can be combined with the desire to preserve nature, which in western countries usually occurs when the material development goes beyond the subsistence level and the environmental values do not interfere with acquiring food or maintaining health.. The history of environmentalism as a social movement is consistent 
with the ideas that changes in social structure are causing changes in values and priorities. Durand [16] claims that the strengthening and the dispersion of environmental values can not be understood only as a logical consequence of the intensification of environmental issues in local and global dimensions that are being pointed out more vigorously since the mid-20th century, or of our scientific and technological capacity to perceive problems inaccessible to our senses. On the contrary, it has to be seen as an action and reaction of the configuration of a new social order.

An interesting fact that Durand [16] also reveals is the lack of correlation between environmental values and city size in Mexico. The inhabitants of cities such as Mexico City, Guadalajara and Monterrey, which have high levels of pollution, do not show a greater concern; neither did they show a more cooperative attitude than inhabitants of less polluted and smaller cities. This phenomenon can be explained as an "adaptation" involving a denial process and suppression of consciousness of environmental risk, in exchange for obtaining other basic or superficial benefits, subordinating the conservation value to others that put more emphasis on short-term than long-term welfare. Durand [16] concludes that living in environmentally degraded areas seem not to involve the emergence of values linked to environmental care, the commitment of action or even the perception of the deteriorated environment.

\section{A Specific Approach of the Mexican Context}

In the environmental field Mexico is a country of contrasts. First of all it is one of the 12 environmentally megadiverse countries of the world. In fact it ranks third among the countries with the greatest biological diversity. It is in the first place with respect to its fauna of reptiles (717 species), second in mammals (451 species), and fourth in amphibians (282 species) and flowering plants (around 25,000 species). 32\% of its national vertebrate fauna are endemic to Mexico, of which 52\% are shared only with other Mesoamerican countries [42,43,45]. The high biological diversity of Mexico is a combined result of both variations in topography and climate found in its territory. These are mixed with each other, creating a mosaic of environmental conditions and micro environments, in addition to the complex geographical background of the area, in particular the southeast part of the country, better known as the Nuclear Central America [44]. There has been major progress in the field of environmental management. Mexico occupies one of the most outstanding places in the world in caring for protected areas, that are being run by the "Comisión Nacional de Areas Naturales Protegidas" (CONANP, National commission of protected natural areas). In 2001 the CONANP was managing 61 protected areas, today it takes care of 171 (23,877.977 ha), more than $97 \%$ of the total protected area of the country. As a result of the effort of the CONANP to preserve the ecosystems and the biodiversity of Mexico, 98.2\% of the protected areas of the country currently enjoy an annual operating program, with skilled human resources and equipment to apply strategies of conservation and development [46].

Worthwhile mentioning aside the above mentioned progress are however some very serious gaps in other fields of environmental management. In terms of legal issues, even though there is a federal law, the environmental rules and norms show a lack of legal consistency as well as some considerable lack of interpretation. Environmental education is also far for being uniform: there are in reality 32 different programs. In terms of economy, while there has been some interesting mechanisms installed to foment the protection, such as payment for environmental services and servitude, some perverse subsidies still remain, the most serious one is for the gasoline that is rather an award for polluting, and among others consequences this subsidies has impeded the technological transitions towards the modernization of the fleet. In terms of organization, the structures of environmental organizations are supported by heavy and inefficient pyramidal function. Likewise some lack of action in metropolitan areas can be observed that provokes the deterioration of the environment. The social participation also shows great backwardness. Indeed it is limited to some hired technical advisory committees that rather allow validating some previous decision taken. On the other hand the non profit organizations are playing an increasingly role but are still at an initial process and do not constitute a social impact that would limit the environmental deterioration.

\section{Evaluation of the Green Behavior of the Mexican Individuals with Respect to the Studied Variables}

As a summary of the deficits in environmental management in Mexico, we could describe it as following. There is a poor orientation man-nature, a very low perceived control by the population that believes that it is the government's responsibility to take care of the environment. The ecological knowledge is very poor too. Indeed there is not one Phd program in environmental education and there are barely three masters programs related to the subject in the 1,200 universities of the country. The personal consequences are appreciated in the upper-level class only and finally the environmental consequences are poorly appreciated in the country. Despite being the country with most national communication launched, there is a big gap between the official programs and the citizen participation. In addition, the highly unequal social structure allows distinguishing at least three cultural 
and social groups:

1) People related to the post-industrial countries, for either working with them of for economic or cultural links.

2) People belonging to the medium class that barely ever leave the country.

3) And at least $40 \%$ of Mexicans that are classified as poor, not only because of their lack of patrimony, but also for nutritional deficiency, and for whom the green behavior, with the exception of a few, represent a difficult concept to understand.

For the first group, one could say that their practices of environmental care are very similar to other post industrialized countries. For the second group of the population, one could claim that there is a growing concern for environmental aspects and finally for the least favored sector of the population, with the exception of a few, the majority has little knowledge about the subject.

\section{Conclusions}

The revision of the variables of the green behavior from the perspective of Mexican individuals shows the relevance of adding aspects of development and social justice in the environmental speech that promotes in Mexico the preservation of the natural environment. The existence of environmental values in sectors that are still struggling for achieving decent standard of living, show that those values are not superfluous components in the vision of the future, but it seems that the connection between a better future and the environmental responsibility is not yet clear to most of Mexicans. It is therefore necessary to expand the interest on environmental issues among Mexicans and generate values in the particular context of different population sectors, so that they can acquire consistency and gain a real sense. It is indeed perceived that in the case of Mexicans, the importance of the environmental component in the quality of life in the short and long term has not been achieved yet. This situation is probably due to the scarcity of economical resources to implement campaigns and projects focused towards the environmental sustainability beyond the local context, but it is maybe also due to the kind of environmentalist speeches that are being publicized that have a strong ecological bias, i.e. they ponderate environmental conservation and the links between the development and the quality of life. Whereas the search for solving more basic and immediate problems, such as acquiring food, maintaining health and keeping a job, or survival issues, should find its sustain in predominant environmental speeches, worried so far essentially for the protection of species and the simple no alteration of the ecosystems.

\section{REFERENCES}

[1] Chan, R. and Lau, L., "Antecedents of green purchases: A survey in China,” Journal of Consumer Marketing, Vol. 20, No. 49, pp. 338-357, 2000.
[2] Follows, S. and Jobber, D., "Environmentally responsible purchase behavior: A test of a consumer model," European Journal of Marketing, No. 5-6, pp. 723-746, 2000.

[3] Kalafatis S., Pollard M., East R., and Tsogas M., "Green marketing and Ajzen's theory of planned behavior: A cross-market examination,” Journal of consumer marketing, Vol. 16, No. 5, pp. 44-46, 1999.

[4] Laroche, M., Bergeron J., and Barbaro-Forleo, G., “Targeting consumers who are willing to pay more for environmentally friendly products,” Journal of Consumer Marketing, Vol. 18, No. 6, pp. 503-520, 2001.

[5] Lopez, A. G., “La preocupación por la calidad del miedo ambiente, Un modelo cognitivo sobre la conducta ecológica,” PH.D. dissertation, Universidad Complutense de Madrid, 2002.

[6] García-Mira, R. and y Real-Deus, E., "Valores, actitudes y creencias: Hacia un modelo predictivo del ambientalismo," Medio ambiente y Comportamiento humano, Vol. 2, No. 1, pp. 21-43, 2001.

[7] Corraliza, J. A. and Martín, R., "Estilos de vida, actitudes y comportamientos ambientales," Medio ambiente y comportamiento humano, Vol. 1, No. 1, pp. 31-56, 2000.

[8] Werner, C. M. and Makela, E., "Motivations and behaviors that support recycling," Journal of environmental psychology, Vol. 18, No. 4, pp. 373-386, 1998.

[9] Corraliza, J. A. and Berenguer, J., “Environmental values, beliefs and actions: A situational approach,” Environment and Behavior, Vol. 32, No. 6, pp. 832-848, 2000.

[10] Gurau, C. and Ranchhod, A., “'International green marketing: A comparative study of british and romanian firms'," International Marketing Review, Vol. 22, No. 5, pp. 547-562, 2005.

[11] Bigné, E.,"El consumidor verde: bases de un modelo de comportamiento”, Esic-Market, Vol. 96, pp. 29-43, april 1997.

[12] Chan, R., "Consumer responses to environmental advertising in China,” Intelligence \& Planning, Vol. 22, No. 4, pp. 427-437, 2004.

[13] Barreiro, J. M., Lopez, M. A., Losada, F., and Ruzo, E., "Análisis de las dimensiones cognoscitiva y afectiva del comportamiento ecológico del consumidor," Revista galega de economía, Vol. 11, No. 2, pp. 1-21, 2002.

[14] Faix, W. G., Kurz, R., and Wichert, F., "Innovation zwischen Ökonomie und Ökologie,” Moderne Industrie Verlag, Landsberg, Lech, 1995.

[15] Castro, R., "Naturaleza y función de las actitudes ambientales,” Estudios de psicología, Vol. 22, No. 1, pp. 11-22, 2001.

[16] Durand, V. M. and Durand, L., "Valores y actitudes sobre la contaminación ambiental en México. Reflexiones en torno al posmaterialismo," Revista mexicana de sociología, Vol. 66, No. 3. pp. 511-535, 2004.

[17] Stern, P. C., Dietz T., and Kalof, L., "Value orientations and environmental concern,” Environment and Behavior, No. 25, pp. 332-348, 1993.

[18] Schultz, P. W., "The structure of environmental concern: 
concern for self, other people, and the biosphere,” Journal of Environmental psychology, Vol. 21, No. 4, pp. 327339, 2001.

[19] Dietz, T., Kalof, L. and Stern, P., "Gender, values, and environmentalism,” Social Science Quartely, Vol. 83, No. 1, pp. 351-364, 2002.

[20] Zelezny, L. C., Chua, P. P., and Aldrich, C., "Elaborating on gender differences in environmentalism," Journal of environmental Psychology, Vol. 18, No. 4, pp. 373-386, 2000.

[21] Connelly, J. and Smith, G., "Politics and the environment: From theory to practice,” London, Routledge, 2002.

[22] Wagner, S. A., "Understanding green consumer behaviour: A qualitative cognitive approach,” London, Rouledge, 2002.

[23] Szarka, J., "The shaping of environmental policy in France,” Contemporary France, New York, Vol. 6, Berghahn, 2002.

[24] Lafferty, W. M. and Meadowcroft, J. R., "Implementing sustainable development: Strategies and initiatives in high consumption societies," Oxford, UK, Oxford University Press, 2000.

[25] Elliott, D., "Energy, society, and environment: Technology for a sustainable future," Routledge, Introductions to Environment Series, New York, Routledge, NY, 2003.

[26] Rivera-Camino, J., "Re-evaluating green marketing strategy: A stakeholder perspective," European Journal of marketing. Vol. 41, No. 11-12, pp. 1328-1358, 2007.

[27] Straughan, R. D. and Roberts, J. A., "Environmental segmentation alternatives: A look at green consumer behavior in the new millennium,” Journal of Consumer marketing, Vol. 16, No. 6, pp. 558-575, 1999.

[28] Tadajewski, M. and Wagner-Tsukamoto, S., “Anthropology and consumer research: qualitative insights into green consumer behavior," Qualitative market research: An international journal, Vol. 9, No. 1, pp. 8-25, 2006.

[29] Hernández, B., Martin, A., Hess, S., Martínez, J., Suárez, E., Salazar, M., et al., "Análisis multidimensional de la percepción del delito ecológico," Medio Ambiente y Comportamiento Humano, No. 6, pp. 51-70, 2005.

[30] Díaz, M. and Palacio, B., "El proceso de adopción de la conducta de reciclado: Modelos explicativos y variables moderadoras," Cuadernos de Economía y Dirección de la Empresa, No. 28, pp. 55-86, 2006.

[31] Pato, C., "Comportamento ecológico: Relações com valores pessoais e crenças ambientais,” PH.d. dissertation, Universidade de Brasília, 2004.
[32] Pato, C. and Tamayo A., "Valores, creencias ambientales y comportamiento ecológico de activismo," Medio Ambiente y Comportamiento Humano, Vol. 7, No. 1, pp. 5166, 2006

[33] D’Souza, C. and Taghian, M., "Green advertising effects on attitude and choice of advertising themes," Asia Pacific Journal of Marketing and Logistics, Vol. 17, No. 3, pp. 51-66, 2005.

[34] Munuera, J. L. and Pemartin, M., "El consumidor europeo de productos ecológicos,” Distribución y consumo, pp. 50-64, January-February 2006.

[35] Kassahye, W. W., „Green dilemma,” Marketing Intelligence \& Planning, Vol. 19, No. 6, pp. 444-455, 2001.

[36] Coddington, W., "Environmental marketing: Positive strategies for reaching green consumers,” Mc Graw Hill, New York, NY, 1993.

[37] Davis, J. J., "Strategies for environmental advertising," Journal of Consumer marketing, Vol. 10, No. 2, pp. 1936, 1993

[38] Ottman, J., "Green marketing, challenges and opportunities for the new marketing age," NTC Business Books, Loncolnwood, IL, 1992

[39] Aguilar, M., Monteoliva, A., and Garcia, J. M., "Influencias de las normas, los valores, las creencias proambientales y la conducta pasada sobre la intención de reciclar," Medio Ambiente y Comportamiento Humano, Vol. 6, No. 1, pp. 23-36, 2005.

[40] Gregson, N. and Crewe, L., "Second-hand cultures, Materializing culture,” Berg, Oxford, 2003.

[41] Ingelhart, R., "Modernization and postmodernization. cultural, economic and political change in 43 societies," New Jersey, Princeton University Press, 1996.

[42] Halffter, G., "La diversidad de Iberoamérica," Acta Zoológica Mexicana, Inst. de Ecología, SEDESOL y CYTED, México, Vol. Especial, 1992.

[43] Retana, O. G. and Lorenzo, C., "Lista de los mamíferos terrestres de Chiapas: Endemismo y estado de conservación,” Acta Zool, Mex., (n.s), No. 85, pp. 25-49. 2002.

[44] Flores, V. O. and Gerez, P., "Biodiversidad y conservación en México: Vertebrados, vegetación y uso del suelo, 2a edición,” CONABIO-UNAM, México, pp. 439, 1994.

[45] Toledo, V. M., "La diversidad biológica de México," Ciencia y Desarrollo, Mexico, 1988.

[46] Comision Nacional de Areas Protegidas, CONANP, 2009, Extracted on the 24 of october, 2009, http://www.conanp.gob.mx/ 